\title{
Platycephalus clavulatus Cantor, 1849 (Teleostei: Platycephalidae), a Junior Synonym of Cociella punctata (Cuvier, 1829)
}

\author{
Taichi Nagao ${ }^{1,2}$ and Hisashi Imamura ${ }^{1,3}$ \\ ${ }^{1}$ Laboratory of Marine Biology and Biodiversity (Systematic Ichthyology), Faculty of Fisheries Sciences, Hokkaido University, \\ 3-1-1 Minato-cho, Hakodate, Hokkaido 041-8611, Japan \\ E-mail:imamura@fish.hokudai.ac.jp \\ ${ }^{2}$ Present address: 13-2 Rokujyo-fukuju-cho, Gifu, Gifu 500-8354, Japan \\ ${ }^{3}$ Corresponding author
}

(Received 20 August 2014; Accepted 1 February 2015)

\begin{abstract}
The validity of the platycephalid species Platycephalus clavulatus Cantor, 1849, described from a single specimen collected in the sea of Pinang (=Penang), Malaysia, is evaluated. Although it has been suggested that the holotype of the species is a specimen registered as BMNH 1860.3.19.270 in the Natural History Museum, London (BMNH), which is identifiable as Cociella punctata (Cuvier, 1829), the total length (TL) of the holotype reported by Cantor is $57 / 8$ inches (=149 mm), significantly longer than the damaged BMNH specimen, which is estimated to have had a TL of $121 \mathrm{~mm}$. According to the original description of $P$. clavulatus, the holotype has 11 second dorsal and anal fin rays, one preorbital spine, and two suborbital spines, values which agree with those of C. punctata, a species widely distributed in the western Pacific and the Indian Ocean, including Penang. Although these characters are also present in Cociella crocodila (Cuvier, 1829), that species is known only from Japan, Korea, China, and Taiwan. We conclude that $P$. clavulatus is conspecific with C. punctata and is a junior synonym of that species.
\end{abstract}

Key Words: Platycephalus clavulatus, taxonomic validity, synonymy, Cociella punctata.

\section{Introduction}

Platycephalus clavulatus was originally described by Cantor (1849) based on a single specimen collected from the sea of Pinang (=Penang), Malaysia. Since the original description, no author has attempted to redescribe it or discuss its taxonomic status, nor has the name of the species appeared in recent publications. Although Eschmeyer (1998) declared the whereabouts of the holotype to be unknown, he subsequently (Eschmeyer 2012) suggested that BMNH 1860.3.19.270 may be the holotype. BMNH 1860.3.19.270, a dry specimen retaining only the left side of the body (Fig. 1), was recorded as being collected in Penang (Fig. 2). It is identifiable as Cociella punctata (Cuvier in Cuvier and Valenciennes, 1829), widely known from the western Pacific and Indian oceans, based on the diagnostic characters of the species presented below. However, its status as type of $P$. clavulatus remains unclear, as its total length (TL) is estimated to have been $121 \mathrm{~mm}$ (see discussion below), while the TL of Cantor's (1849) holotype was stated to be $57 / 8$ inches $(=149 \mathrm{~mm})$. After detailed comparison of the original description of $P$. clavulatus with species known from Penang and adjacent waters, we have concluded that the former is

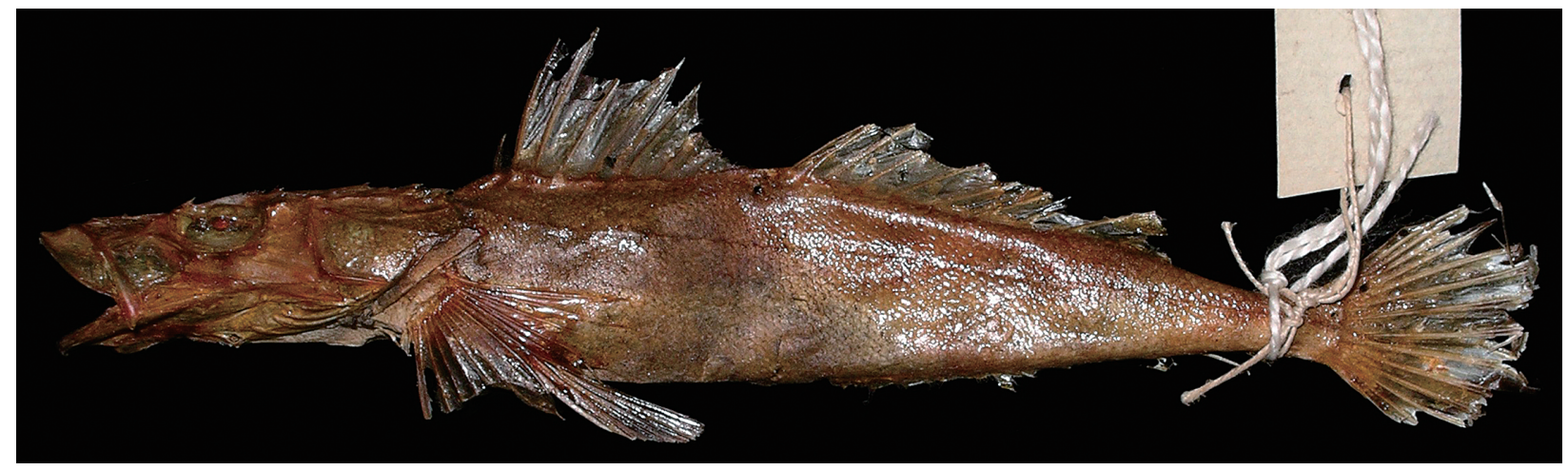

Fig. 1. Lateral view of BMNH 1860.3.19.270, collected at Pinang (=Penang), Malaysia, identified here as Cociella punctata. 




Fig. 2. Labels attached to BMNH 1860.3.19.270. A, front sides; B, back sides.

a junior synonym of $C$. punctata. This publication discusses the rationale behind this conclusion.

\section{Materials and Methods}

Counts and measurements follow Imamura (2008). Measurements were made with calipers to the nearest $0.1 \mathrm{~mm}$ accuracy. Orbital diameter was measured in an anterodorsal to posteroventral direction, as this is the maximum diameter in many platycephalids aside from Platycephalus Bloch, 1795. Interorbital width was measured level with the eye center. Terminology of head spines follows Knapp et al. (2000). Institutional acronyms are from Eschmeyer (1998), except for the Hokkaido University Museum, Hakodate (HUMZ), Natural History Museum and Institute, Chiba $(\mathrm{CMNH})$, National Museum of Nature and Science, Tsukuba (NSMT), and South African Institute of Aquatic Biodiversity (SAIAB).

\section{Results and Discussion}

BMNH 1860.3.19.270 is identified as Cociella punctata because it possesses diagnostic characters of the species, including 11 second dorsal and anal fin rays, about 65 scale rows above the lateral line slanting downward and forward, a single preorbital spine, two suborbital spines, one exterior opening on each of the lateral line scales, an interopercular flap, and small dark spots on the dorsal parts of the head and body (Knapp 1999). It has no identifiable differences in other counts and proportions from the specimens of $C$. punctata we have examined, including three syntypes (Table $1)$.

Although the BMNH specimen is labeled a "paratype" (Fig. 2), it cannot be a paratype of $P$. clavulatus, because the species was apparently described on the basis of only the holotype [Cantor (1849: 1021) stated, "The present species of which a single, apparently young, individual was observed in Pinang in $1843, . . . . '$. Discrepancies between the length of this specimen and the stated length of the holotype of $P$. clavulatus also place some doubt on whether they are the same. Cantor (1849) gave the TL of the holotype as $57 / 8$ inches $(=149.2 \mathrm{~mm})$, but BMNH 1860.3.19.270 possesses a broken caudal fin, preventing a direct measurement of its TL. However, after comparing the relationships of TL and standard length (SL) in 28 specimens of C. punctata, the TL of the damaged BMNH 1860.3.19.270 was calculated to have been $121 \mathrm{~mm}$, based on its SL of $100 \mathrm{~mm}$ and a regression line expressed as $\mathrm{y}(\mathrm{TL})=1.1907 \times(\mathrm{SL})+1.9087\left(R^{2}=0.9990\right)$. Consequently, we regard the identity of BMNH 1860.3.19.270 as the holotype of $P$. clavulatus unproven. The following analysis of the taxonomic status of $P$. clavulatus is based on a comparison of its original description with species known from Penang and adjacent waters.

According to the original description of $P$. clavulatus, the species has one preorbital and two suborbital spines [described by Cantor (1849: 1021) as, "On the middle of the anterior infraorbital bone is a small reclining spine; on the posterior two distant (maybe meaning distinct) larger, ...."], and these are present in the BMNH specimen as well. Within the Platycephalidae, this condition is present only in Elates ransonnetii (Steindachner, 1876), smaller specimens of many species of Platycephalus, and members of the genus Cociella Whitley, 1940, except for Cociella hutchinsi Knapp, 1996, which is known only from Australia and has five or six suborbital spines and no or one preorbital spine (Knapp 1996, 1999; Imamura 2015). Although E. ransonnetii, Platycephalus cultellatus Richardson, 1846, and Platycephalus indicus (Linnaeus, 1758) are also distributed in the western Malay Peninsula and adjacent waters, $P$. clavulatus apparently differs from them in having 11 second dorsal and anal fin rays rather than 13 as they usually have (Knapp 1999; Imamura 2012; this study). The number of suborbital spines tends to increase with growth in some platycephalids [i.e., Suggrundus meerdervoortii (Bleeker, 1860): Imamura et al. (1996); Inegocia japonica Cuvier in Cuvier and Valenciennes, 1829, Onigocia macrolepis (Bleeker, 1854), Onigocia spinosa (Temminck and Schlegel, 1843), and Rogadius asper (Cuvier in Cuvier and Valenciennes, 1829): Hirota and Sasaki (1998); and four species of Onigocia Jordan and Thompson, 1913: Imamura (2011)]. Knapp (1999) reported the following platycephalid species with three or more suborbital spines from Penang and adjacent waters: Grammoplites knappi Imamura and Amaoka, 1994; Grammoplites scaber (Linnaeus, 1758); Kumococcius rodericensis (Cuvier in Cuvier and Valenciennes, 1829); Rogadius pristiger (Cuvier in Cuvier and Valenciennes, 1829); Rogadius tuberculatus (Cuvier in Cuvier and Valenciennes, 1829); Suggrundus macracanthus (Bleeker, 1869); Sunagocia carbunculus (Va- 
Table 1. Comparison of counts and proportional measurements of Platycephalus clavulatus and Cociella punctata.

\begin{tabular}{|c|c|c|c|c|c|c|}
\hline & \multicolumn{2}{|c|}{ Platycephalus clavulatus } & \multicolumn{4}{|c|}{ Cociella punctata } \\
\hline & \multirow{2}{*}{$\begin{array}{c}\text { Holotype } \\
\text { Cantor } \\
(1849)\end{array}$} & \multirow{2}{*}{$\frac{\text { Holotype? }}{\text { BMNH }}$} & \multicolumn{3}{|c|}{ Syntypes $(n=3)$} & \multirow{2}{*}{$\begin{array}{l}\text { Others } \\
n=34\end{array}$} \\
\hline & & & MNHN 5836 & MNHN 6851 & MNHN 6852 & \\
\hline $\mathrm{SL}(\mathrm{TL})(\mathrm{mm})$ & $124 *(149)$ & $100\left(121^{*}\right)$ & $179(-)$ & $188(-)$ & $239(-)$ & $72.5-293(87.6-351)$ \\
\hline \multicolumn{7}{|l|}{ Counts: } \\
\hline First dorsal fin rays & VIII (total) & I+VIII & $\mathrm{I}+\mathrm{VIII}$ & $\mathrm{I}+\mathrm{VIII}$ & $\mathrm{I}+\mathrm{VIII}$ & $\mathrm{I}+\mathrm{VIII}$ \\
\hline Second dorsal fin rays & 11 & 11 & 11 & 11 & 11 & 11 \\
\hline Anal fin rays & 11 & 11 & 11 & 11 & 11 & 10-11 (usually 11) \\
\hline $\begin{array}{l}\text { Pectoral fin rays (upper unbranched }+ \\
\text { branched }+ \text { lower unbranched) }\end{array}$ & $?+?+?=20$ & $?+?+?=19$ & $2+10+8=20$ & $2+12+7=21$ & $2+11+7=20$ & $1-3+9-13+6-11=19-22$ \\
\hline Pelvic fin rays & $\mathrm{I}, 5$ & $\mathrm{I}, 5$ & I, 5 & $\mathrm{I}, 5$ & I, 5 & I, 5 \\
\hline Branched caudal fin rays & $153 / 3 * *$ & 12 & 11 & 12 & 11 & $10-13$ \\
\hline Pored scales in lateral line (with spine) & $-(-)$ & $-(-)$ & $54(12)$ & $54(6)$ & $54(5)$ & $51-54(2-27)$ \\
\hline $\begin{array}{l}\text { Scale rows above lateral line slanting downward } \\
\text { and backward }\end{array}$ & - & ca. 65 & 65 & - & 75 & $58-74$ \\
\hline Gill rakers & - & - & $1+5=6$ & $1+5=6$ & $1+5=6$ & $1+4-6=5-7$ (usually 6$)$ \\
\hline \multicolumn{7}{|l|}{ Proportional measurements (\% SL): } \\
\hline HL & - & 34.8 & 33.1 & 33.2 & 32.6 & $32.5-36.9$ \\
\hline Predorsal length & - & 34.3 & 35.0 & 35.1 & 33.7 & $33.7-37.4$ \\
\hline Length of first dorsal fin base & - & 19.6 & 21.1 & 20.3 & 19.8 & $18.3-21.9$ \\
\hline Length of second dorsal fin base & - & 31.1 & 28.4 & 28.5 & 27.4 & $26.7-29.4$ \\
\hline Length of anal fin base & - & 30.8 & 32.4 & 31.1 & 31.8 & $28.3-35.2$ \\
\hline Length of caudal peduncle & - & 10.1 & 10.1 & 10.1 & 10.0 & $8.8-13.3$ \\
\hline Depth of caudal peduncle & - & 4.7 & 5.1 & 4.7 & 4.5 & $4.2-5.5$ \\
\hline Snout length & - & 9.5 & 9.7 & 10.0 & 9.8 & $9.5-11.3$ \\
\hline Orbital diameter & - & 7.7 & 8.1 & 8.3 & 7.9 & $6.7-9.4$ \\
\hline Upper jaw length & - & 12.4 & 12.4 & 12.2 & 11.9 & $11.8-14.0$ \\
\hline Lower jaw length & - & 18.4 & 20.1 & 19.7 & 19.0 & $18.6-21.8$ \\
\hline Interorbital width & - & - & 2.3 & 2.1 & 2.5 & $1.9-3.1$ \\
\hline Pectoral fin length & - & - & 16.3 & 16.5 & 15.9 & $13.6-17.3$ \\
\hline Pelvic fin length & - & - & 28.2 & 29.1 & 28.4 & $18.2-31.1$ \\
\hline Caudal fin length & - & - & 19.3 & - & 18.9 & $16.1-22.3$ \\
\hline \multicolumn{7}{|l|}{ Proportional measurements (\% HL): } \\
\hline Snout length & - & 27.2 & 29.3 & 30.2 & 30.1 & $28.1-32.6$ \\
\hline Orbital diameter & - & 22.1 & 24.6 & 25.1 & 24.3 & $19.8-26.6$ \\
\hline Upper jaw length & - & 35.5 & 37.4 & 36.6 & 36.6 & $35.6-38.9$ \\
\hline Lower jaw length & - & 53.0 & 60.8 & 59.4 & 58.4 & $54.9-62.1$ \\
\hline Interorbital width & - & - & 7.1 & 6.4 & 7.6 & $5.7-9.2$ \\
\hline
\end{tabular}

Dash (-) indicates data unavailable; * Estimated based on morphometrics of 28 specimens of C. punctata; ** Counting method unknown.

lenciennes in Cuvier and Valenciennes, 1833); Thysanophrys celebica (Bleeker, 1855); and Thysanophrys chiltonae (Schultz in Schultz et al., 1966) [see diagnoses of genera in Imamura (1996) for usual number of spines on suborbital ridge, including both preorbital and suborbital spines]. An examination of the species listed above revealed that the smallest examined specimens, which are smaller than the holotype of P. clavulatus, already have four or more suborbital spines or serration on the suborbital ridge (Table 2), a situation that excludes them as potential synonyms. Consequently, it appears that $P$. clavulatus belongs to the genus Cociella. In the following discussion, we compare P. clavulatus and species of Cociella, with the exception of $C$. hutchinsi for the reasons mentioned above.

Among the four known relevant species of Cociella, $C$. punctata is known from Penang [see also the list of examined material of C. punctata in Knapp (1996), including
Table 2. Numbers of suborbital spines (NSO) in smallest examined specimens of nine species of platycephalid.

\begin{tabular}{lccc}
\hline \multicolumn{1}{c}{ Species } & SL (mm) & TL $(\mathrm{mm})$ & NSO (left/right) \\
\hline Grammoplites knappi & 70.3 & 84.9 & $4 / 4$ \\
Grammoplites scaber & 92.6 & 108 & $4 / 5$ \\
Kumococius rodericensis & 64.8 & - & $4 / 4$ \\
Rogadius pristiger & 63.8 & - & serration/serration \\
Rogadius tuberculatus & 65.0 & 79.6 & serration/serration \\
Suggrundus macracanthus & 56.4 & 67.6 & $4 / 4$ \\
Sunagocia carbunculus & 46.9 & 58.5 & $4 / 4$ \\
Thysanophrys celebica & 32.1 & - & $4 / 4$ \\
Thysanophrys chiltonae & 54.9 & 68.4 & $4 / 5$ \\
\hline
\end{tabular}

Dash (-) indicates data unavailable.

those from Penang], while the other three have not been reported from there [Cociella crocodila (Cuvier in Cuvier and Valenciennes, 1829) from Japan, Korea, China, and Taiwan, 
and Cociella heemstrai Knapp, 1996 and Cociella somaliensis Knapp, 1996 from the western Indian Ocean; see Knapp (1996)]. The original description of $P$. clavulatus states that the species has 11 second dorsal and anal fin rays, and 20 pectoral fin rays, as does C. punctata (Table 1). Although some taxonomic characters that are useful in separating C. punctata and C. crocodila were not described by Cantor (1849) [i.e., numbers of gill rakers and scale rows above lateral line slanting downward and backward, and presence or absence of interopercular flap; see Knapp (1996)], C. heemstrai and C. somaliensis usually possess 12 second dorsal and anal fin rays (Knapp 1996), different from the counts in C. punctata (and also P. clavulatus). Cantor (1849) gave the dorsal fin spine number in P. clavulatus as eight whereas $C$. punctata has nine in total (I+VIII). Among the platycephalids known from Penang and adjacent waters, few species have eight dorsal fin spines even as a variation of the count, and the species having it usually do not have both $11 \mathrm{sec}-$ ond dorsal and anal fin rays [i.e., S. curbanculus, T. celebica, and T. chiltonae with eight or nine dorsal fin spines in total, but usually 12 anal fin rays, 12 second dorsal and 13 anal fin rays, and 12 anal fin rays, respectively; see Knapp (1999)]. In addition, in our experience the last dorsal fin spine is short and sometimes easily overlooked in platycephalids, while mistakes in counting second dorsal and anal fin rays rarely occur. We think the report of the eight dorsal fin spines in $P$. clavulatus is likely to be erroneous.

As a consequence of all these considerations, we regard $P$. clavulatus as conspecific with C. punctata; $P$. clavulatus thus becomes a junior synonym of C. punctata, which has priority.

Comparative material. Cociella punctata (37 specimens). Syntypes: MNHN 6836, 179 mm SL, MNHN 6851, $188 \mathrm{~mm}$ SL, Trincomalee; MNHN 6852, 239 mm SL, Vanicoro.

Other types. BMNH 1872.10.18.117, holotype of Platycephalus fasciatus Günther 1872, $191 \mathrm{~mm}$ SL, Luzon Is., Philippines; BMNH 1880.4.21.102, paralectotype of $P$. bataviensis or Bleeker's specimen, $91.7 \mathrm{~mm} \mathrm{SL}$, Batavia (=Jakarta), Indonesia (or locality unknown in latter case); MNHN 6848, holotype of Platycephalus malabaricus Cuvier in Cuvier and Valenciennes, 1829, 215 mm SL, Mahé, India; RMNH 5915, 3 syntypes of Platycephalus quoyi Bleeker, 1856-57, $126-178 \mathrm{~mm} \mathrm{SL}, 2$ of the 3 from Ambon or Ternate Island, Indonesia.

Non-types. India: SU 41735 (2), 160-168 mm SL. Indonesia: BMNH 1984.1.1.65, $265 \mathrm{~mm}$ SL; NSMT-P 55454, 126 mm SL; USNM 327289 (4), 72.8-147 mm SL. Japan: NSMT-P 29286, 72.5 mm SL; NSMT-P 57007, $132 \mathrm{~mm}$ SL. Palau: CAS 81322, 128 mm SL; USNM 329288, 250 mm SL. Philippines: HUMZ 198665, 277 mm SL; CAS-SU 27207, $176 \mathrm{~mm}$ SL. Red Sea: MNHN 6845, $209 \mathrm{~mm}$ SL; NMW 11167, 162 mm SL; NMW 11718, 165 mm SL; NMW 11719, $160 \mathrm{~mm}$ SL. Singapore: NMW 11171 (2), 173-176 mm SL. South Africa: SAIAB 1519, $156 \mathrm{~mm}$ SL; SAIAB 1520, $131 \mathrm{~mm}$ SL. Sri Lanka: USNM 340853, $220 \mathrm{~mm}$ SL. Thailand (Indian Ocean): FRLM 30670, $122 \mathrm{~mm}$ SL; PMBC uncat., 293 mm SL. Thailand (western Pacific): ANSP 62861,
150 mm SL. Tanzania: USNM 326291, 195 mm SL. Vietnam: MNHN 1905-222, 167 mm SL.

Other species. Grammoplites knappi: NSMT-P 70943, $70.3 \mathrm{~mm}$ SL (84.9 mm TL), Thailand, western Pacific. Grammoplites scaber: HUMZ 201968, $92.6 \mathrm{~mm} \mathrm{SL} \mathrm{(108} \mathrm{mm} \mathrm{TL),}$ Malacca Strait. Kumococcius rodericensis: MNHN 6900, $64.8 \mathrm{~mm}$ SL (TL not measured owing to damaged caudal fin), holotype of Platycephalus timorensis Cuvier in Cuvier and Valenciennes, 1829, Timor. Rogadius pristiger: CAS 52338, 63.8 mm SL (TL not measured), Celebes. Rogadius tuberculatus: URM-P 15156, 65.0 mm SL (79.6 mm TL), Japan. Suggrundus macracanthus: NSMT-P 112069, $56.4 \mathrm{~mm}$ SL (67.6 mm TL), Thailand. Sunagocia carbunculus: PMBC 20659 (1 of 6), $46.9 \mathrm{~mm}$ SL (58.5 mm TL), Phuket, Thailand. Thysanophrys celebica: ZMA 112435 (1 of 2 syntypes of Platycephalus horai de Beaufort, 1956), $32.1 \mathrm{~mm}$ SL (TL not measured owning to damaged caudal fin), Ceram Sea. Thysanophrys chiltonae: CMNH-ZF 13962, $54.9 \mathrm{~mm} \mathrm{SL}$ (68.4 mm TL), Japan. Examined specimens of Platycephalus, including $P$. cultellatus and $P$. indicus, are listed in Imamura (2012).

\section{Acknowledgments}

We express our sincere thanks to M. F. Gomon (NMV), who critically read the draft manuscript of this paper. Our thanks also go to M. Yabe (Hokkaido University, Hakodate) and T. Kawai (HUMZ) for giving constructive suggestions during this study. We are deeply indebted to M. Aizawa (formerly CMNH), M. E. Anderson (SAIAB), G. Duhamel, P. Pruvost, and R. Causse (MNHN), T. Iwamoto, D. Catania, and M. Hoang (CAS), S. Kimura (FRLM), K. Matsuura and G. Shinohara (NSMT), J. Macline (BMNH), M. J. P. van Oijen (RMNH), M. H. Sabaj Pérez (ANSP), C. Aungtonya and U. Satapoomin (PMBC), R. Vonk (ZMA), H. Wellendorf (NMW), J. T. Williams and P. Diane (USNM), T. Yoshino (formerly URM), and all other staff of the fish sections of the mentioned museums for making specimens available. This study was partly supported by "Japan Society for the Promotion of Science (JSPS) Asian Core Program-Establishment of research and education network on coastal marine science in Southeast Asia" and JSPS KAKENHI Grant Number 2544019603.

\section{References}

Cantor, T. E. 1849. Catalogue of Malayan fishes. Journal of the Asiatic Society of Bengal 18 (2): i-xii +983-1443, pls 1-14.

Eschmeyer, W. N. 1998. Collection abbreviations. Pp. 16-22. In: Eschmeyer, W. N. (Ed.) Catalog of Fishes. Vols. 1-3. California Academy of Sciences, San Francisco.

Eschmeyer, W. N. (Ed.) 2012. Catalog of fishes: genera, species, references. Online version, updated 23 July 2012. http://research. calacademy.org/research/ichthyology/catalog/fishcatmain.asp. Accessed 20 August 2014.

Hirota, M. and Sasaki, K. 1998. Development of juveniles of four flatheads (Perciformes, Platycephalidae) occurring in southern Japan. 
Ichthyological Research 45: 291-301.

Imamura, H. 1996. Phylogeny of the family Platycephalidae and related taxa (Pisces: Scorpaeniformes). Species Diversity 1: 123-233.

Imamura, H. 2008. Synonymy of two species of the genus Platycephalus and validity of Platycephalus westraliae (Pisces: Scorpaeniformes). Ichthyological Research 55: 399-406.

Imamura, H. 2011. Onigocia sibogae, a replacement name for a distinct species of flathead fish, Platycephalus grandisquamis Weber, 1913 (Teleostei: Platycephalidae). Zootaxa 3066: 52-60.

Imamura, H. 2012. Redescription of Platycephalus angustus Steindachner 1866 (Teleostei: Platycephalidae), a valid flathead in northern Australia and New Guinea. Ichthyological Research DOI: 10.1007/s10228-012-0319-6. (also appeared in Ichthyological Research 60: 112-121 published in 2013)

Imamura, H. 2015. Taxonomic revision of the flathead fish genus Platycephalus Bloch, 1785 (Teleostei: Platycephalidae) from Australia, with description of a new species. Zootaxa 3904: 151-207.

Imamura. H., Yabe, M., Iguchi, M., and Amaoka, K. 1996. Juvenile development of a flathead, Suggrundus meerdervoortii (Scorpaeniformes: Platycephalidae). Ichthyological Research 43: 47-53.

Knapp, L. W. 1996. Review of the genus Cociella Whitley (Teleostei: Platycephalidae) with the description of three new species. Proceedings of the Biological Society of Washington 109: 17-33.

Knapp, L. W. 1999. Platycephalidae. Pp. 2385-2421. In: Carpenter, K. E. and Niem, V. H. (Eds) FAO Species Identification Guide for Fishery Purposes. The Living Marine Resources of Western Central Pacific, Vol. 4. Bony Fishes Part 2 (Mugilidae to Carangidae). FAO, Rome.

Knapp, L. W., Imamura, H., and Sakashita, M. 2000. Onigocia bimaculata, a new species of flathead fish (Scorpaeniformes: Platycephalidae) from the Indo-Pacific. Special Publication of the J. L. B. Smith Institute of Ichthyology (64): 1-10. 